\title{
KERJASAMA BISNIS KECIL DENGAN JARINGAN RITEL, DALAM MENINGKATKAN DAN MEMPERLUAS DISTRIBUSI INDUSTRI PRODUK TAS DI TANGGULANGIN SIDOARJO
}

\author{
M. Miftach Farid ${ }^{1)}$, Dicky Fajar Maulana ${ }^{2)}$ \\ ${ }^{1,2)}$ Program Studi Manajemen, Universitas Narotama Surabaya \\ ${ }^{1)}$ E-Mail: faridzouzo@gmail.com \\ ${ }^{2)}$ E-Mail: \{ HYPERLINK "mailto:dickyfajar303@gmail.com" \}
}

\begin{abstract}
In the era of this free market to improve the performance of small business actors in developing their business needed a real strength and partnership between small business actors as the party that produces goods with the ritail network with the goal of creating a mutual cooperation. The positive impact that can be felt with this partnership program is to make unhealthy competition between them in the long term. Because modern mini market is a container that directly related to the end consumer in selling various kinds of goods needs and other supporting goods. While small business actors also require market segments to sell all forms of goods in the production. This collaboration ultimately creates a mutually beneficial condition between small business actors and mini markets that serve to sell or ritail ing from small business products into modern ritail. This is a model that must be turned on to increase synergy between producers or small business actors with modern ritail both in rural and urban environments.
\end{abstract}

Keywords: business partnership, ritail network, product distribution.

Abstrak. Di era pasar bebas ini untuk meningkatkan kinerja pelaku usaha kecil dalam mengembangkan usahanya diperlukan kekuatan dan kemitraan nyata antara pelaku usaha kecil sebagai pihak yang menghasilkan barang dengan jaringan ritail dengan tujuan menciptakan kerja sama yang saling menguntungkan. Dampak positif yang bisa dirasakan dengan program kemitraan ini adalah membuat persaingan tidak sehat di antara mereka dalam jangka panjang. Karena pasar mini modern adalah wadah yang langsung berhubungan dengan konsumen akhir dalam menjual berbagai macam kebutuhan barang dan barang pendukung lainnya. Sementara pelaku usaha kecil juga membutuhkan segmen pasar untuk menjual semua bentuk barang dalam produksi. Kolaborasi ini pada akhirnya menciptakan kondisi yang saling menguntungkan antara pelaku usaha kecil dan pasar mini yang berfungsi untuk menjual atau ritail ing dari produk usaha kecil ke dalam ritail modern. Ini adalah model yang harus dihidupkan untuk meningkatkan sinergi antara produsen atau pelaku usaha kecil dengan ritail modern baik di lingkungan pedesaan maupun perkotaan.

Kata kunci: kemitraan bisnis, jaringan ritail, distribusi produk.

\section{PENDAHULUAN}

Sejalan dengan perkembangan saat ini di Indonesia dari tahun ke tahun, pemenuhan kebutuhan hidup, terutama yang menyangkut kebutuhan primer dan sekunder, terus meningkat. Hal ini menyebabkan orang yang bertindak sebagai 
konsumen menginginkan proses pembelian barang kebutuhan sehari-hari harus dibuat lebih mudah, yang saat ini kita semua mengenalnya sebagai tempat belanja yang mudah dan langsung. Ini mendorong pengusaha untuk berinvestasi di bidang bisnis ritel dan mengembangkannya. Dengan munculnya bisnis ritel baru ini tentu dapat mempengaruhi pangsa pasar yang ada. Untuk itu (Artaya, dkk, 2018), perlu meningkatkan layanan kepada konsumen dan pemulihan strategi layanan yang tepat agar konsumen yang telah menguasai dapat dipertahankan atau dapat meningkatkan konsumen yang ada, dalam hal ini itu dapat disajikan oleh pengusaha bisnis ritel yang menempatkan bisnis ritel saha yang kita kenal sebagai Ritail dalam skala kecil.

Fenomena yang terjadi selama bidang ini adalah:

1. Ritail adalah perusahaan waralaba yang bergerak dalam penjualan produk yang digunakan oleh konsumen dalam kehidupan sehari-hari.

2. Banyaknya kebutuhan primer dan sekunder yang harus dipenuhi oleh konsumen menyebabkan konsumen menginginkan proses pembelian barang dengan mudah dan langsung.

3. Harga, lokasi dan hadiah yang ditawarkan oleh produk termasuk faktor-faktor yang dapat mempengaruhi minat konsumen.

Beberapa hambatan yang muncul dan menjadi hambatan meliputi:

1. Kemampuan ritail dalam memberikan jasanya kepada kepuasan konsumen terhadap harga barang yang dijual.

2. Kemampuan rital dalam memberikan layanan kepada kepuasan konsumen terhadap kuantitas dan kualitas barang yang dijual.

3. Kemampuan ritail modern dalam memberikan layanan untuk kepuasan konsumen terhadap fasilitas tempat yang memberikan kenyamanan bagi setiap konsumen yang melakukan transaksi atau melakukan pembelian barang yang ditawarkan oleh ritail.

4. Kemampuan Ritail dalam memberikan layanan untuk kepuasan pelanggan terhadap sikap karyawan Ritail dalam melayani pelanggannya.

5. Menurunnya tingkat layanan sebagai akibat dari kegagalan dalam pengiriman layanan pelanggan.

\section{KAJIAN TEORI}

\section{Kemitraan Bisnis Umum}

Menurut Yurindra (2017), Kemitraan adalah kerja sama dari dua atau lebih orang yang bersama-sama memiliki bisnis dengan tujuan menghasilkan keuntungan. Bentuk kemitraan yang kita kenal adalah perusahaan dan CV. Firma adalah bentuk kemitraan di mana semua mitra berpartisipasi aktif dalam menjalankan bisnis dan bertanggung jawab bersama. $\mathrm{CV}$ adalah bentuk kemitraan yang mengakui keberadaan mitra aktif dan pasif (komanditer). Mitra aktif adalah mitra yang memiliki, mengoperasikan, dan mengelola bisnis dan memiliki kewajiban tidak terbatas terhadap utang kemitraan, sedangkan mitra kemitraan adalah anggota kemitraan yang tidak memiliki peran aktif dalam mengelola perusahaan dan kewajibannya atas utang kemitraan sejauh uang yang diimplementasikannya. Manfaat yang dapat diperoleh melalui kemitraan adalah:

1. Kemapanan mudah. Dalam kasus pendirian perusahaan individu, pembentukan kemitraan dapat dilakukan dengan cara informal hanya jika tidak perlu menjadikan bisnis kemitraan formal dan tercatat.

2. Keterampilan pelengkap. Salah satu alasan memilih pasangan adalah keterbatasan dalam melakukan sesuatu. Misalnya, jika bisnisnya masih kecil, semua kegiatan mulai dari mencari pelanggan hingga menghasilkan dapat dilakukan sendiri. Namun, ketika prospek bisnis semakin besar, terkadang 
aktivitas pemasaran yang memakan waktu dengan rapat dan lobi mengharuskan seorang pengusaha membutuhkan mitra yang mengawasi masalah teknis produksi.

3. Bagi hasil relatif lebih mudah. Ini dapat dilakukan dengan kesepakatan bersama yang ditetapkan pada awal kerjasama. Bagi hasil tidak harus sama dengan rasio modal, mengingat beban kerja dan tanggung jawab dalam menjalankan bisnis.

4. Kemudahan dalam mencari mitra pasif (komandan). Mitra kemitraan dianggap sebagai bentuk bisnis kemitraan yang dikuasai karena dapat mengakomodasi orang-orang yang bersedia berinvestasi tanpa terlibat langsung dalam bisnis, dan bersedia mengambil risiko hanya sejauh uang yang diinvestasikan. Selain itu, dalam bentuk kemitraan seperti ini, membuka peluang untuk mencari modal yang lebih besar bagi inisiator suatu bisnis (mitra aktif).

5. Peningkatan modal yang lebih besar. Jika memang mitra yang sangat cocok, dan mau berinvestasi sama dan aktif dalam usaha patungan, tentu saja ini membuat modal awal sebuah bisnis menjadi lebih besar. Terutama ketika digabungkan dengan komitmen yang mencapai properti pribadi, membuat kemungkinan untuk ekspansi bisnis karena modal yang lebih besar menjadi sangat mungkin.

6. Fleksibilitas. Karena kemitraan ini biasanya merupakan bentuk usaha kecil, fleksibilitas dalam beradaptasi dengan dunia bisnis dan kecepatan dalam membuat keputusan adalah suatu keuntungan.

\section{Peran Ritailing}

Menurut Wahyono (2012) dalam artikelnya, peran perusahaan ritail dapat digambarkan sebagai berikut:

1. Menyediakan pasokan / pasokan barang dan jasa kapan dan ketika dibutuhkan oleh konsumen / pelanggan dengan sedikit atau tanpa penundaan.

2. Memfasilitasi konsumen / pelanggan dalam memilih atau membandingkan bentuk, kualitas dan barang dan jasa yang ditawarkan.

3. Menjaga harga jual rendah agar dapat bersaing dalam memuaskan pelanggan

4. Membantu meningkatkan taraf hidup masyarakat

5. Adanya bisnis ritel juga memungkinkan produksi skala besar (produksi massal).

\section{Fungsi Ritel}

Sedangkan fungsi dari aktivitas ritailing, dapat dijelaskan sebagai berikut:

1. Melakukan kegiatan bisnis di lokasi yang nyaman dan mudah diakses oleh pelanggan

2. Menyediakan berbagai produk yang memungkinkan pelanggan memilih produk yang diinginkan

3. Bagilah sejumlah besar produk sehingga mereka dapat dijual dalam kemasan / ukuran kecil

4. Ubah produk menjadi bentuk yang lebih menarik.

5. Jaga produk tersedia dengan harga yang relatif tetap

6. Membantu mengubah (transfer) kepemilikan barang dari produsen ke konsumen

7. Menyebabkan pergerakan barang melalui sistem distribusi

8. Memberikan informasi, tidak hanya kepada pelanggan, tetapi juga kepada pemasok

9. Memberikan jaminan produk layanan purna jual, dan berpartisipasi dalam menangani keluhan pelanggan

10. Menyediakan fasilitas kredit dan sewa. 


\section{Pola Hubungan Ritailing Dengan Pengusaha Kecil Pengusaha}

Artaya, et al (2018), pola hubungan yang seimbang di sini adalah bahwa di satu sisi perusahaan yang membutuhkan berbagai jenis produk dari pemasok, dan pemasok dapat berasal dari kegiatan usaha kecil yang produknya dinyatakan memenuhi kelayakan didistribusikan di kegiatan penjualan oleh waralaba. Para franchisee memperoleh barang yang diperdagangkan dari pasokan barang yang diproduksi oleh usaha kecil, sehingga dalam jangka panjang, beberapa usaha kecil akan dapat menjadi mitra tetap untuk bisnis wiralaba yang dijalankan dalam upaya memenuhi kebutuhan konsumen sehari-hari. barang. Di sisi lain, barang-barang yang dihasilkan oleh pelaku usaha kecil menjadi terdistribusi lebih cepat dengan adanya aktivitas atau bisnis ritailing yang tumbuh sesuai dengan tekanan dan dorongan pertumbuhan ekonomi baik di daerah pedesaan maupun perkotaan. Namun, dalam membangun kerjasama yang terkait dengan kegiatan ekonomi, pemerintah harus dapat membuka peluang melalui peraturan yang dapat langsung dirasakan oleh pelaku usaha kecil (Soekiman et al, 2018), mengapa demikian, untuk usaha kecil dengan waralaba perusahaan dapat beroperasi dengan saling menguntungkan satu sama lain, dan tidak satu pun dari mereka saling merugikan. Perusahaan kereta api waralaba dapat diwujudkan dalam bentuk koperasi. Kondisi ini sangat membantu pelaku usaha kecil dalam mendistribusikan produknya ke pasar atau konsumen dan didistribusikan lebih nyata.

\section{METODE PENELITIAN}

\section{Lokasi Penelitian}

Lokasi penelitian adalah tas industri dan koper Tanggulangin Sidoarjo, Jawa Timur, yang merupakan pusat industri kerajinan sejak kulit terbesar 1976 di Jawa Timur. Pusat kerajinan kulit memang unggulan dari Sidoarjo.

\section{Subjek Penelitian}

Yang menjadi subjek dalam penelitian ini adalah sekelompok pengrajin atau industri rumahan tas dagang dan koper di tanggulangin, semuanya berjumlah 18 pengrajin yang memiliki produksi dengan orientasi pasar ekspor.

\section{Data Penelitian}

Yang menjadi subjek dalam penelitian ini adalah sekelompok pengrajin atau industri rumahan tas perdagangan dan koper di tanggulangin, semuanya berjumlah 18 pengrajin yang memiliki produksi dengan orientasi pasar ekspor.

\section{Model Analisa Data}

Untuk keperluan analisis data penelitian, model analisis regresi linier menggunakan dobel, di mana persamaan dapat ditunjukkan dari analisis dan di bawah ini:

$$
\mathrm{Y}=\mathrm{bo}+\mathrm{b} 1 . \mathrm{X} 1+\mathrm{b} 2 . \mathrm{X} 2+\mathrm{b} 3+\mathrm{e}
$$

Di mana:

$$
\begin{array}{ll}
\mathrm{Y} & =\text { Jaringan Ritel } \\
\mathrm{X} 1 & =\text { Manfaat Produk } \\
\mathrm{X} 2 & =\text { Harga Jual Produk } \\
\mathrm{X} 3 & =\text { Kualitas Produk }
\end{array}
$$

b1, b2, b3 yang merupakan parameter regresi AS adalah keputusan dalam estimasi aktivitas, yang menandai nilai kecilnya.

(e) = nilai variabel pengganggu yang tidak dibahas dalam model. 
HASIL DAN PEMBAHASAN

Hasil analisis regresi linier berganda untuk keperluan analisis dan diskusi dapat ditunjukkan seperti yang disajikan di bawah ini:

Tabel 1. Hasil analisis regresi linier berganda

Model Summary

\begin{tabular}{|c|c|r|r|r|}
\hline Model & $\mathrm{R}$ & $\mathrm{R}$ Square & $\begin{array}{c}\text { Adjusted R } \\
\text { Square }\end{array}$ & $\begin{array}{c}\text { Std. Error of the } \\
\text { Estimate }\end{array}$ \\
\hline 1 &, $921^{\mathrm{a}}$ &, 849 &, 816 &, 303 \\
\hline
\end{tabular}

a. Predictors: (Constant), The Quality Of The Product, The Selling

Price Of The Product, Product Benefits

b. Dependent Variable: Retailing Network

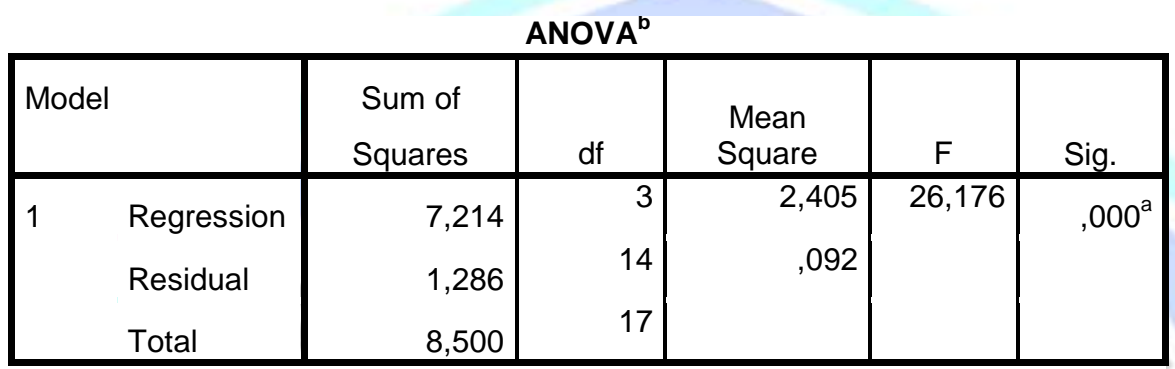

a. Predictors: (Constant), The Quality Of The Product, The Selling Price Of The Product, Product Benefits

b. Dependent Variable: Retailing Network

Coefficients $^{\mathrm{a}}$

\begin{tabular}{|c|c|c|c|c|c|c|}
\hline \multirow{2}{*}{\multicolumn{2}{|c|}{ Model }} & \multicolumn{2}{|c|}{$\begin{array}{c}\text { Unstandardized } \\
\text { Coefficients }\end{array}$} & \multirow{2}{*}{$\begin{array}{c}\begin{array}{c}\text { Standardized } \\
\text { Coefficients }\end{array} \\
\text { Beta }\end{array}$} & \multirow[b]{2}{*}{ t } & \multirow[b]{2}{*}{ Sig. } \\
\hline & & $\mathrm{B}$ & Std. Error & & & \\
\hline \multirow[t]{4}{*}{1} & (Constant) &,- 933 & ,606 & & $-1,539$ & , 146 \\
\hline & Product Benefits & ,847 & ,130 & ,766 & 6,509 & ,000 \\
\hline & $\begin{array}{l}\text { The Selling Price Of } \\
\text { The Product }\end{array}$ & ,238 & ,126 & ,208 & 1,893 & ,079 \\
\hline & $\begin{array}{l}\text { The Quality Of The } \\
\text { Product }\end{array}$ & 118 & ,087 & , 152 & 1,355 & , 197 \\
\hline
\end{tabular}

a. Dependent Variable: Retailing Network

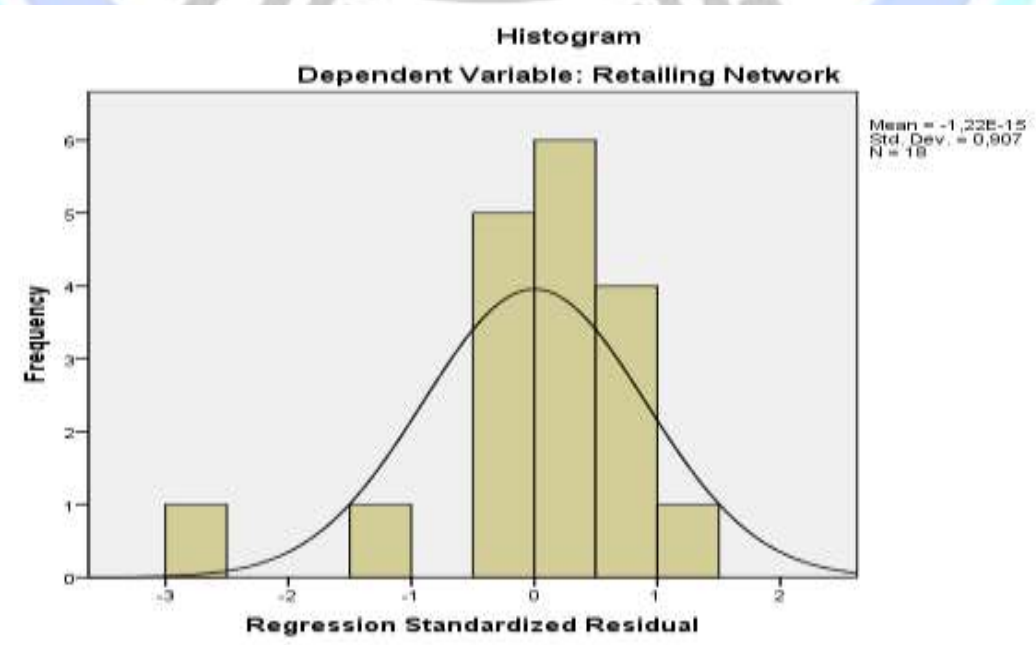




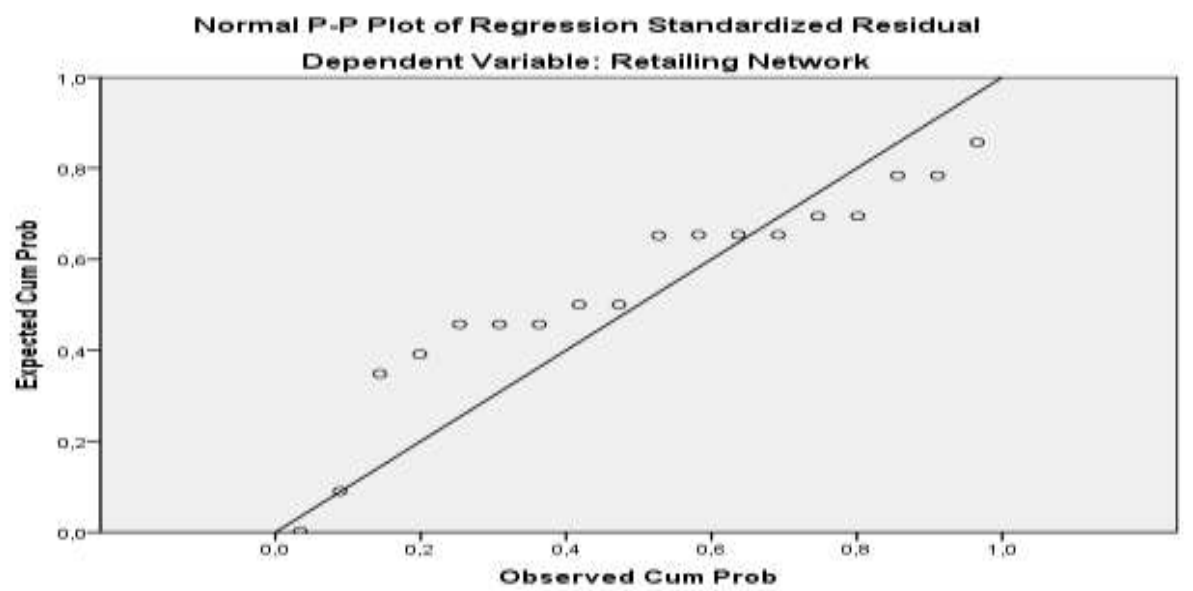

\section{HASIL DAN PEMBAHASAN}

Dengan melihat hasil analisis dan hasil regresi linier berganda di atas, ada beberapa hal yang perlu kita diskusikan dan simpulkan, sebagai berikut:

1. Manfaat Produk, dapat berjalan dengan baik ketika produk yang diperdagangkan memiliki kelebihan, dan dari hasil analisis ternyata menjadi signifikan, yang berarti bahwa produk dari kelompok industri tas dan koper di Tanggulangin memang memiliki kelebihan untuk penjualan komoditas di aktivitas ritel. Makna dari kegiatan ini telah berjalan dengan baik karena hasil analisisnya signifikan.

2. Harga Jual Produk, hasil penjualan produk hasil analisisnya ternyata tidak signifikan. Berarti harga jualnya masih belum mampu bersaing dengan kompetitor dalam upaya memperluas penjualan melalui kegiatan ritel. Tentunya ini harus lebih banyak pengrajin Fokus kelompok melakukan efisinensi pada produksi seoptimal mungkin untuk menekan harga jual produk, sehingga produk yang dijual dalam kegiatan ritel bisa diserap oleh pasar.

3. Kualitas Produk, hasil pengujian menunjukkan tidak signifikan. Ini berarti bahwa untuk dapat bersaing melalui jaringan ritel, kualitas produk bukanlah jaminan, karena pesaing juga memiliki kualitas produk yang setara, sehingga Kelompok pengrajin harus dapat memiliki upaya yang lebih baik dalam bentuk peningkatan memodelkan dan merancang produk sedemikian rupa sehingga dapat menjadi faktor untuk meningkatkan nilai tambah produk.

\section{PENUTUP}

\section{Simpulan}

Berdasarkan studi dan diskusi tentang kerangka teoritis di atas, kita dapat membuat kesimpulan sebagai berikut:

1. Tanpa kemitraan atau kemitraan, usaha kecil dan lembaga waralaba (ritail) karena satu sama lain tidak saling mengenal dan pengaruhnya dapat saling mematikan, sehingga dampak ekonomi yang menguntungkan tidak akan terjadi.

2. Antara usaha kecil dan waralaba (ritail) jika terjalin kerja sama, tentu sinergi antara keduanya akan dapat membawa manfaat dan saling menguntungkan dalam jangka panjang.

3. Pelaku usaha kecil adalah produsen atau produsen produk, sementara waralaba adalah bisnis ritail yang menawarkan atau menjual produk usaha kecil dan waralaba atau ritail yang memperoleh manfaat ekonomi dari bisnis yang dilakukan. 


\section{Saran}

1. Ritail atau bisnis waralaba, jika kehadirannya mampu menjalin hubungan baik dengan pelaku usaha kecil, kehadiran pasar mini modern sebagai wujud nyata dari bisnis waralaba di Indonesia, tidak akan membawa atau menyebabkan tabrakan ekonomi dalam kondisi sehari-hari yang nyata.

2. Dengan kehadiran waralaba (ritailing), maka pelaku usaha kecil merasakan manfaat yang akan membawa keuntungan tersendiri sehingga pelaku usaha kecil perlahan mampu menembus pasar bebas, karena produk usaha kecil menjadi lebih dikenal secara luas di luar negeri.

\section{DAFTAR RUJUKAN}

Artaya, I Putu. 2013, Wiraniaga-Membangun Jaringan Penjualan, Narotama University Press, Surabaya.

Artaya, I Putu. 2018, Dasar-Dasar Manajemen Operasi Dan Produksi, Narotama University Press, Surabaya.

Artaya, I Putu. Arimbawa, IG, 2018, Penerapan Metode Korelasi dalam Mengukur Hubungan Antara Customer Relationship dengan Customer Loyalty Pada PT. Antika Raya Surabaya, Jurnal Bisnis dan Manajemen Universitas Negeri Surabaya. Vol. 1, No. 1.

Artaya, IP. Kamisutara, Made., Baktiono, R Agus., 2018, Pengaruh Citra Produk Berdasarkan Analisis Persepsi Konsumen Pada Kelompok Usaha Aneka Pangan Di Sidoarjo, E-Jurnal Tata Sejuta STIA Mataram, Vol. 4, No. 1.

Reily, Michael. 2017, Kemendag Luncurkan Kemitraan Ritail dan Pedagang Kecil, 02 Nopember 2017, (\{ HYPERLINK "https://katadata.co.id/berita/2017/11/02/kemendag-luncurkankemitraan-retail-modern-dan-pedagang-kecil" \}).

Santoso, Singgih., 2015., Mengukur Sikap dan Kepuasan Konsumen Aplikasi SPSS, Penerbit Elex Media Komputindo, Jakarta.

Wahyono, Budi. 2012, Peran Dan Fungsi Perusahaan Ritel, 12 Juni 2012, (\{ HYPERLINK "http://www.pendidikanekonomi.com/2012/06/peran-danfungsi-usaha-ritel.html" \}).

Yurindra, Rama. 2017, Bentuk Usaha Kemitraan-Keuntungan dan Kerugian, 02 Juni 2017, (\{ HYPERLINK "http://www.tsoekarsono.com/2017/06/02/seri-ukmbentuk-usaha-kemitraan-keuntungan-dan-kerugian/" \}). 